\title{
STUDENTŲ FIZINIO AKTYVUMO INTENSYVUMAS SU SVEIKATA SUSIJUSIOS GYVENIMO KOKYBËS KONTEKSTE
}

\author{
Rita Jankauskienė, Gražina Šniepienė \\ Klaipédos valstybinè kolegija
}

Raktažodžiai: fizinio aktyvumo intensyvumas, su sveikata susijusi gyvenimo kokybe, kineziterapijos programos studentai.

\begin{abstract}
Santrauka
Informacija apie su sveikata susijusios gyvenimo kokybės rodiklius yra svarbi vertinant sveikatos rizikos, sveikatos socialinius veiksnius, sveikatos sistemos efektyvumą, kuriant sveikatos gerinimo ir prevencijos programas, nustatant prioritetinius sveikatos ir valstybès politikos tikslus. Tyrimo tikslas - ivvertinti Klaipèdos valstybinès kolegijos kineziterapijos programos studentų fizinio aktyvumo intensyvumą, kaip su sveikata susijusios gyvenimo kokybès veiksni. Tyrimas atliktas naudojantis Pasaulio sveikatos organizacijos (PSO) pasiūlytu tarptautiniu fizinio aktyvumo klausimynu (angl. Global physical activity questionnaire - GPAQ) ir taikant jo vertinimo metodiką. Vertintas studentų fizinis aktyvumas darbo metu ar ji atitinkančioje kasdienèje veikloje, laisvalaikio metu ir judant iš vienos vietos ị kitą norint susisiekti bei pasyviai (sėdint) praleidžiamas laikas. Respondentai pagal bendrą fizinès veiklos intensyvumą suskirstyti ị žemo, vidutinio ir aukšto fizinio aktyvumo kategorijas. Tiriamujų imtị sudarè 127 Klaipèdos valstybinès kolegijos kineziterapijos programos studentai (86 proc. moterų ir 14 proc. vyrų). Amžiaus vidurkis $-24,67 \pm 3,76$ metai. İvertintas studentų pasitenkinimas gyvenimo kokybe: patenkintų ir labai patenkintų yra 5 kartus daugiau (65\%), nei nepatenkintu ir labai nepatenkintų (13\%). 22 proc. apklaustujų tvirtos nuomonès nepareiškè. Panašią tendenciją išryškino ir pasitenkinimo sveikata vertinimas: patenkintų ir labai patenkintu yra 4 kartus daugiau, lyginant su nepatenkintais ir labai nepatenkintais savo sveikata studentais. Didžioji dalis (74 proc.) respondentų studijų metu nedirba. Dirbančių studentų darbas dažniausiai susijęs su fizine veikla (71 proc. dirbančių studentų). Laisvalaikiu užsiimantys (52 proc.) ir neužsiimantys
\end{abstract}

(48 proc.) fizine veikla pasiskirstè panašiai. Fizinès veiklos trukmé per parą vidutiniškai apie 30 minučių. Nagrinèjant apklausos rezultatus apie sėdèjimo elgseną darbo dienomis ir laisvalaikiu, nustatyta, kad darbo dienomis dažniausiai studentai sėdi 5-6 valandas per parą. Sèsliai praleidžiančių laisvalaikị nuo 1 iki 6 valandų per parą procentas yra panašus ir sudaro $25-27$ proc. nuo visų apklaustujjų. Ir darbe, ir laisvalaikiu studentams būdinga vidutinio intensyvumo fizinè veikla. Gauti rezultatai galètų suteikti pagrindą studentų sveikatingumo programoms ir veiklai kurti, kad būtų nuosekliai ugdomas sveikatos supratimas, formuojamas sveikos gyvensenos stilius, teikiamos sveikos gyvensenos rekomendacijos, sveikatos išsaugojimo programos.

\section{İvadas}

Gyvenimo kokybės aktualijos darnaus visuomenès vystymosi laikotarpiu užima svarbią vietą įvairių mokslo sričių - medicinos, ekonomikos, socialinio darbo, psichologijos, antropologijos ir kt. tyrimuose. Kompleksinis tarpdisciplininis požiūris ị visuomenès ar atskirų jos grupių ịvairius gyvenimo kokybės aspektus ịgalina plačiai suvokti daugelị visuomenès problemų. Ypač tai svarbu šiandieniniame gyvenime, kai socialinè, ekonominè, kultūrinè, politiné, ekologinè aplinka yra labai dinamiška ir veikianti žmogaus gyvenimo kokybę. Medicinos mokslo ir sveikatos priežiūros srityje analizuojama siauresnè gyvenimo kokybès sritis, apibūdinama kaip su sveikata susijusi gyvenimo kokybė [1]. Šie tyrimai plačiai taikomi ir medicinos klinikinejje praktikoje, ir kaip visuomenès sveikatos stebėsenos priemonè, vertinant sveikatos rizikos, sveikatos socialinius veiksnius, sveikatos sistemos efektyvumą, kuriant sveikatos gerinimo ir prevencijos programas, nustatant prioritetinius sveikatos ir valstybès politikos tikslus [2-3].

Viena pagrindinių sveikatos komponenčių yra fizinè sveikata, kuriai turi ịtakos fizinis aktyvumas. Reguliaria fizine veikla užsiimančio žmogaus kūne vykstantys morfologiniai ir funkciniai pakitimai gali padèti išvengti lètinių ligų (širdies 
ir kraujagyslių, diabeto, kai kurių rūšiu vęžio, depresijos ir kt.) arba jas atitolinti [4-6]. Nepakankamas fizinis aktyvumas yra vienas iš pagrindinių mirtingumo rizikos veiksnių, todèl sveiki suaugę žmonès turètų užsiimti ne mažiau kaip 30 minučių vidutinio intensyvumo fizine veikla 5 dienas per savaitę arba ne mažiau kaip 20 minučiu labai intensyvia fizine veikla 3 dienas per savaitę [7].

Didejjantis aplinkos automatizavimas ir kompiuterizavimas mažina poreiki judèti visose amžiaus grupèse [4], todèl jaunimo fizinès būklès ir sveikatos blogèjimo tendencija kelia didelį susirūpinimą visuomenès sveikatos specialistams ir medikams. Lietuvoje jaunimas sudaro apie 20 proc. šalies gyventojų, iš kurių dauguma studentai. Studijos aukštojoje mokykloje yra reikšmingas gyvenimo ịvykis, nes pasikeičia studentų gyvensena, dienotvarké, didèja protinès veiklos krūvis, ilgèja fiziškai pasyvaus laiko, praleidžiamo prie kompiuterio, studijose ar vykdant užduotis, trukmè, mažèja fizinis aktyvumas [8]. Dažnai šie pokyčiai reikalauja didesnių asmens pastangų derinti intensyvų protinị darbą su fiziniu aktyvumu, kurios gali lemti pervargimą ir tapti sveikatos sutrikimo priežastimi.

Tyrimo tikslas - ịvertinti Klaipėdos valstybinès kolegijos kineziterapijos programos studentų fizinio aktyvumo intensyvumą, kaip su sveikata susijusios gyvenimo kokybès veiksnị. Darbe įvertintas studentų aukšto, vidutinio bei žemo fizinio aktyvumo santykis bus panaudotas didinti jų vidinę motyvaciją ir poreiki judéti.

\section{Tyrimo medžiaga ir metodai}

Fizinio aktyvumo intensyvumui įvertinti tiriamujų imti sudare Klaipèdos valstybinès kolegijos kineziterapijos programos 127 studentai (86 proc. moterų ir 14 proc. vyrų). Apklausa atlikta, gavus kolegijos Bioetikos komisijos lei-

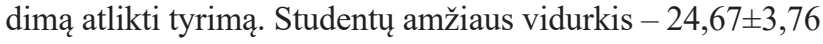
metai. Vedusių (ištekèjusių) studentų skaičius sudarè 5,5

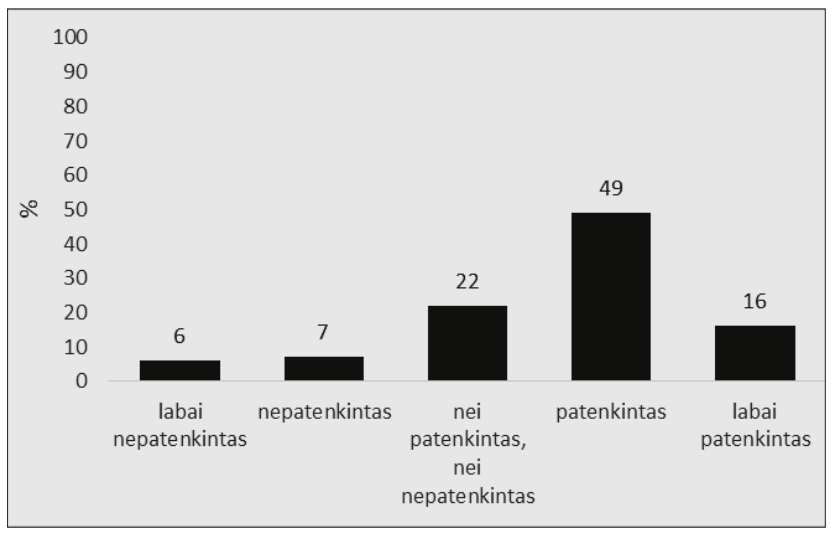

1 pav. Respondentų pasiskirstymas pagal pasitenkinimą savo gyvenimo kokybe. proc., nevedusių (netekejusių) - 83,46 proc. Didžioji dalis (74 proc.) respondentų studijų metu nedirba. Vidutinès pajamos - 231,57 \pm 92.37 eurų per mènesị.

Tyrimas atliktas naudojantis PSO pasiūlytu GPAQ klausimynu, taikant jo vertinimo metodiką [9]. Studentų fizinis aktyvumas vertintas pagal 1) bendrą fizinès veiklos intensyvumą ir bendrą fizinès veiklos trukmę valandomis per parą; 2) fizini aktyvumą skirtingose veiklos srityse - darbe, laisvalaikio metu ir judant iš vienos vietos ị kitą.

Bendram fizinès veiklos intensyvumui išreikšti, remiantis PSO GPAQ analizès metodika, naudoti medžiagų apykaitos ekvivalentai (angl. metabolic equivalents, MET). Medžiagų apykaitos ekvivalentas rodo santykị tarp žmogaus medžiagų apykaitos lygio dirbant ir jo medžiagų apykaitos lygio ilsintis. 1 MET minutès reikšmè, prilygstanti energijos sąnaudoms ramiai sẻdint, ekvivalentiška $1 \mathrm{kcal} / \mathrm{kg} / \mathrm{val}$. Pagal šią metodiką analizuojant duomenis, buvo laikomasi tokių prielaidų: palyginus su ramiu sėdèjimu, žmogus suvartoja 4 kartus daugiau kalorijų, užsiimdamas vidutinio intensyvumo fizine veikla $(M E T$ verte $=4,0)$ ir 8 kartus daugiau kalorijų, užsiimdamas didelio intensyvumo fizine veikla (MET verte $=8,0$ ). Taikant PSO GPAQ analizès metodiką, respondentai pagal bendrą fizinès veiklos intensyvumą suskirstyti į žemo, vidutinio ir aukšto fizinio aktyvumo kategorijas. Aukštas fizinis aktyvumas - aukšto intensyvumo veikla bent 3 dienas, pasiekiant bent 1500 MET minučių per savaitę, arba 7 dienas ejjimas pésčiomis (važiavimas dviračiu) bei bet kokio intensyvumo (didelio ar vidutinio) fizinè veikla, pasiekiant mažiausiai 3000 MET minučių per savaitę. Vidutinis fizinis aktyvumas -3 ar daugiau dienų didelio intensyvumo veiklos bent 20 minučiu per parą, arba 5 ar daugiau dienų vidutinio intensyvumo veikla ne mažiau nei 30 minučių per parą, arba 5 ar daugiau dienų, derinant èjimą pėsčiomis (važiavimą dviračiu) ir vidutinio ar didelio intensyvumo veiklas, minimaliai

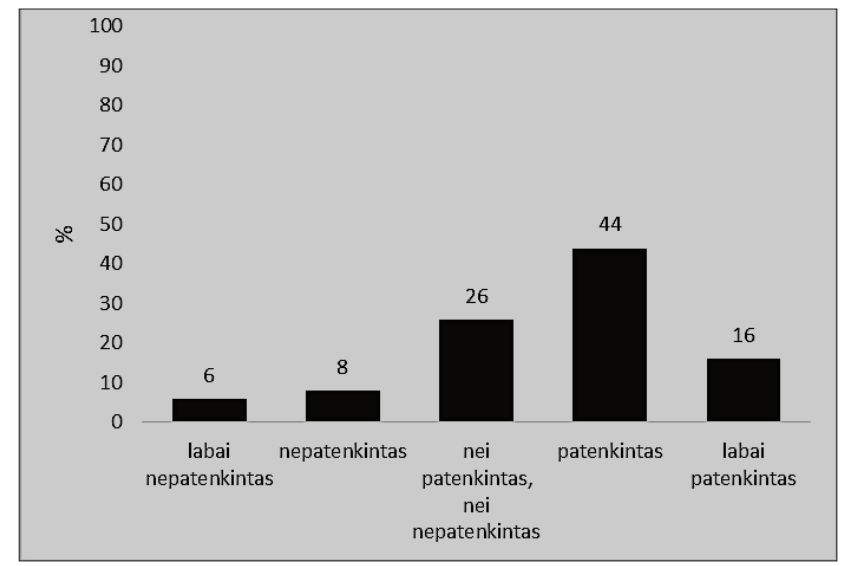

2 pav. Respondentų pasitenkinimas savo sveikata. 
pasiekiant 600 MET minučių per savaitę. Žemas fizinis aktyvumas - neatitinkantis anksčiau išvardytų kriterijų. Vidutinè fizinio aktyvumo trukmè vertinta valandomis per parą.

Fizinis aktyvumas skirtingose srityse (darbo, laisvalaikio ir judèjimo iš vienos vietos ị kitą) nagrinètas nustatant fiziškai neaktyvių asmenų dali (procentais) ir apskaičiuojant fiziškai aktyvių asmenų vidutinę fizinio aktyvumo trukmę valandomis. Fiziškai neaktyviais asmenimis laikyti respondentai, kurie neužsiëmè vidutinio ir didelio intensyvumo fizine veikla.

Statistinè duomenų analizè atlikta naudojant SPSS programinę įrangą. Atsakymų dažnio skirtumų tarp lyginamųų grupių patikimumas tikrintas chi kvadrato $\left(\chi^{2}\right)$ kriterijumi. Vertinant respondentų fizinio aktyvumo skirtumus, buvo remiamasi šiais reikšmingumo lygmenimis: jei reikšmingumo lygmuo $p>0,05$, skirtumai tarp dažnių yra statistiškai nereikšmingi; jei $\mathrm{p}<0,05$, skirtumai statistiškai reikšmingi; jei $p<0,01$ - skirtumas esminis; jei $p<0,001$ - skirtumas labai ryškus; jei $\mathrm{p}<0,0001$ - visiškas skirtumas.

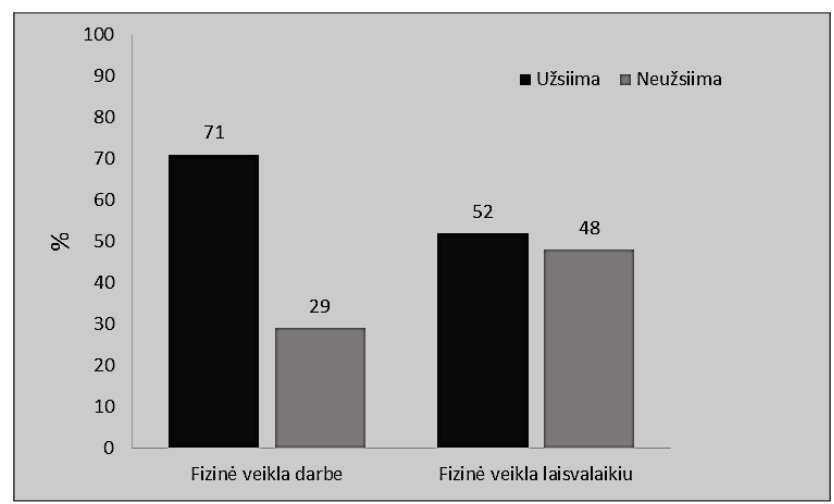

3 pav. Respondentų fizinė veikla darbe ir laisvalaikiu.

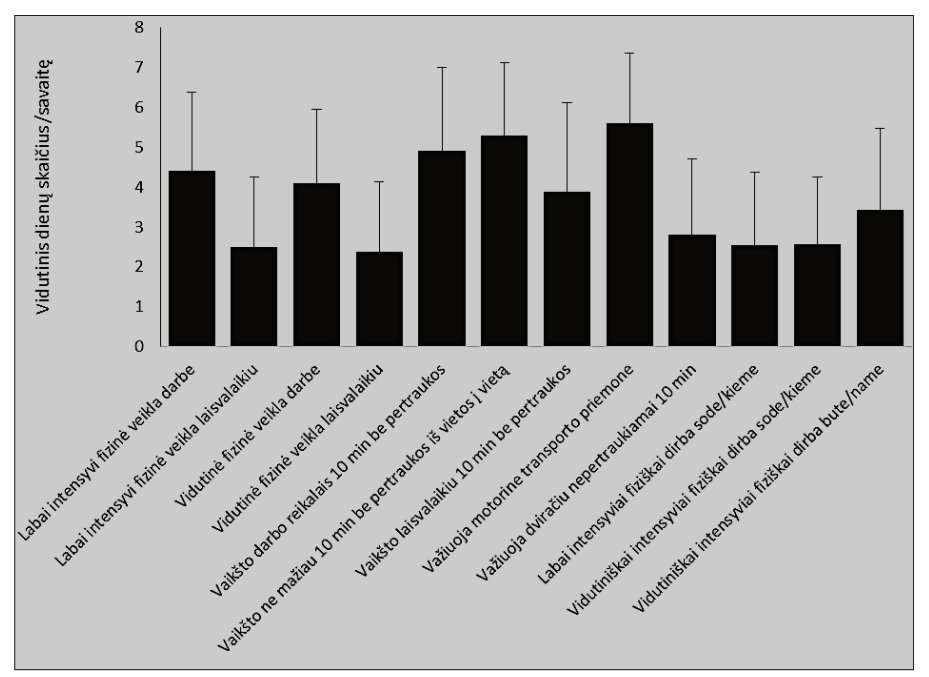

4 pav. Fizinès veiklos vidutinis dažnis (dienomis per savaitę).

\section{Rezultatai}

Tyrimo metu ịvertintas studentu pasitenkinimas gyvenimo kokybe (1 pav.). Nustatyta, kad savo gyvenimo kokybe patenkintų ir labai patenkintų yra 5 kartus daugiau (65 proc.), nei nepatenkintų ir labai nepatenkintų (13 proc.). 22 proc. apklaustujų tvirtos nuomonès nepareiškè $\left(\chi^{2}=77,94 ; \mathrm{df}=\right.$ 4; $\mathrm{p}<0,0001)$.

Panaši tendencija nustatyta ir ịvertinus pasitenkinimą sveikata (2 pav.).

Patenkinti ir labai patenkinti savo sveikata buvo 60 proc. studentu, t.y. 4 kartus daugiau, lyginant su nepatenkintais ir labai nepatenkintais (14 proc.). 26 proc. apklaustujų tvirtos nuomonès apie pasitenkinimą savo sveikata neturèjo $\left(\chi^{2}=\right.$ $63,48 ; \mathrm{df}=4 ; \mathrm{p}<0,0001)$.

Dirbančių studentų darbo pobūdžiui dažniausiai būdinga fizinè veikla (71 proc. dirbančių studentų) $\left(\chi^{2}=80,6 ; \mathrm{df}=2\right.$; $\mathrm{p}<0,0001$ ) (3 pav.). Laisvalaikiu užsiimantys fizine veikla $(52 \%)$ ir ja neužsiimantys $(48 \%)$ pasiskirstė panašiai $(p>$ $0,05)$.

Lyginant atskiras fizinio aktyvumo veiklos sritis pagal pasireiškimo dažnį, nustatyta, kad darbe fizinis aktyvumas reiškiasi apie 2 kartus dažniau, nei laisvalaikiu (4 pav.).

Nustatytas statistiškai reikšmingas skirtumas tarp labai intensyvios ir vidutiniškai intensyvios veiklos dažnio darbe ir laisvalaikiu $\left(\chi^{2}=275,22 ; \mathrm{df}=7 ; \mathrm{p}<0,0001\right.$ ir $\chi^{2}=353,19$; $\mathrm{df}=6 ; \mathrm{p}<0,0001$ atitinkamai). Dažniausiai studentai vairuoja motorinę transporto priemonę, o dviračiu važiuoja perpus rečiau. Tarp šių veiklos formų nustatytas statistiškai reikšmingas skirtumas $\left(\chi^{2}=278,68 ; \mathrm{df}=6 ; \mathrm{p}<0,0001\right)$.

Fizinès veiklos trukmè per parą yra panaši ir vidutiniškai trunka apie 30 minučių, išskyrus labai intensyvią veiklą darbe, kuri, lyginant su kitomis veiklos sritimis, trunka dvigubai trumpiau (5 pav.). Tarp labai intensyvios veiklos darbe ir laisvalaikiu nustatytas statistiškai reikšmingas skirtumas $\left(\chi^{2}=265,21 ; \mathrm{df}=3 ; \mathrm{p}<0,0001\right)$.

Nagrinéjant apklausos rezultatus apie sèdèjimo laiką darbo dienomis ir laisvalaikiu, nustatyta, kad studentai darbo dienomis dažniausiai sèdi 5-6 valandas per parą (6 pav.).

Panaši tendencija išlieka ir laisvalaikiu. Sèsliai praleidžiančių laisvalaikị nuo 1 iki 6 valandų per parą procentas yra panašus ir sudaro 25-27 proc. nuo visų apklaustų studentų. Nustatytas statistiškai reikšmingas skirtumas tarp sèdejjimo elgsenos darbe ir laisvalaikiu $\left(\chi^{2}=60,02 ; \mathrm{df}=13 ; \mathrm{p}<0,0001\right)$.

Ir darbe, ir laisvalaikiu studentams būdinga vidutinio intensyvumo fizinè veikla (7 pav.).

Tarp atskiru fizinio aktyvumo intensyvumo grupių nustatytas statistiškai reikšmingas skirtumas $\left(\chi^{2}\right.$ $=334,76 ; \mathrm{df}=3 ; \mathrm{p}<0,0001)$. 


\section{Rezultatų aptarimas}

Mokslininkų nuomone, žinios apie fizinį aktyvumą formuoja asmens sąmoningą požiūrị ị sveikatą ir ją stiprinančius veiksnius, padeda ịtvirtinti kasdienius sveikatai naudingus ịpročius bei gebėjimus [10]. Studentų atsakymai ị klausimą „Kaip labai jūs patenkinti savo gyvenimo kokybe?“ labai optimistiški: patenkintų ir labai patenkintų buvo 5 kartus daugiau (65 proc. apklaustų studentų) nei nepatenkintų ir labai nepatenkintu (13 proc.) $(\mathrm{p}<0,0001)$. Stebima koreliacija tarp studentu pasitenkinimo gyvenimo kokybe ir pasitenkinimo sveikata. Patenkintų ir labai patenkintų savo sveikata buvo 60 proc., tai yra 4 kartus daugiau, lyginant su nepatenkintais ir labai nepatenkintais savo sveikata (14 proc.). Gyvenimo kokybė yra plati sąvoka. Daugelyje mokslo sričių ji gali būti nagrinèjama skirtingais lygmenimis, lemiama daugelio veiksnių ir aplinkybių, tačiau šiame darbe galima daryti prielaidą, kad studentai gyvenimo kokybę sieja su sveikata. Sveikas žmogus gali reikštis fizinèje, protinèje ir socialinèje plotmėse, susikurdamas teigiamą emocinę būseną - visuminị

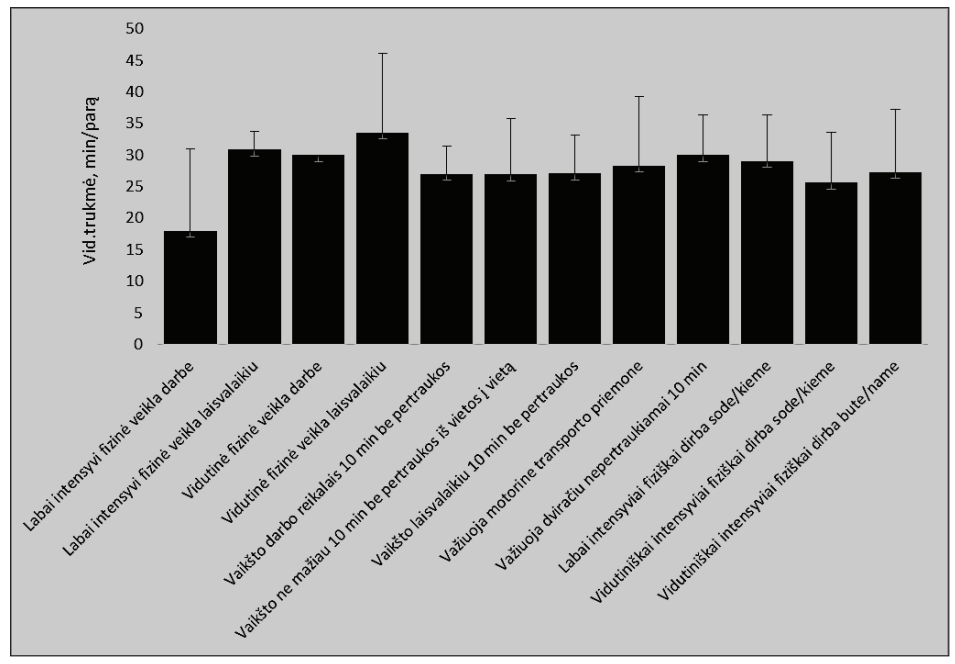

5 pav. Vidutiné fizinės veiklos trukmė (min. per parą).

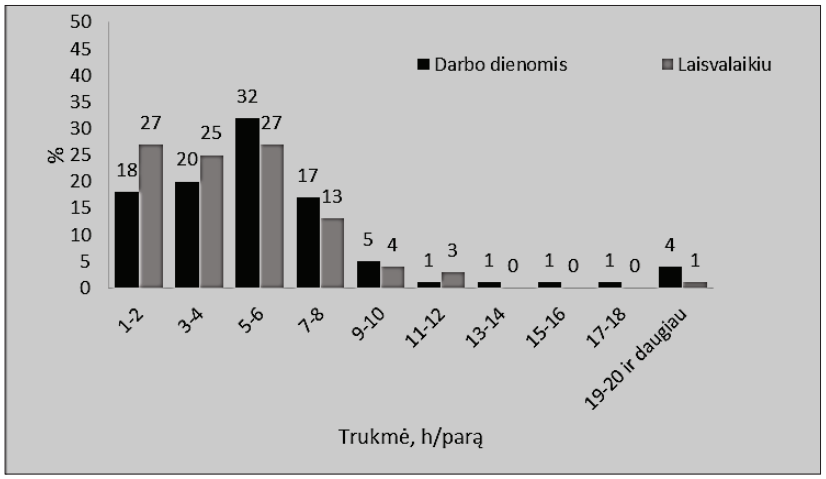

6 pav. Sèdèjimo laikas darbo dienomis ir laisvalaikiu (h/parą).

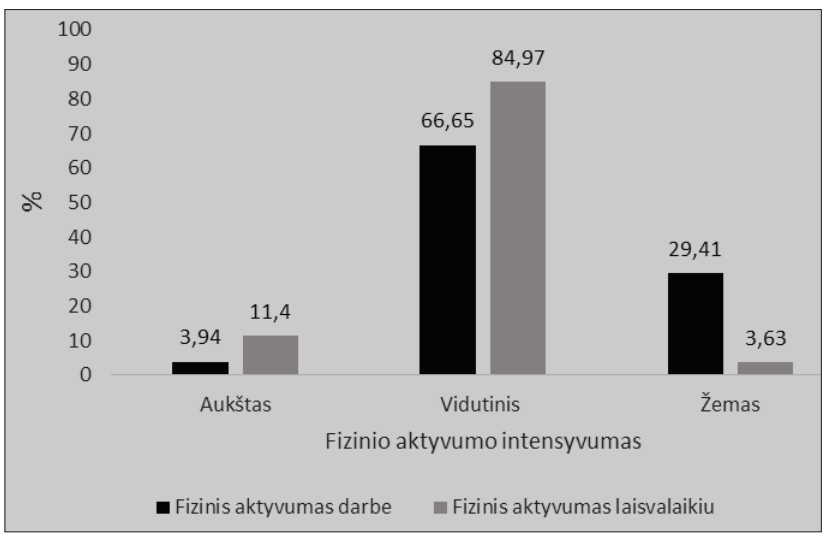

7 pav. Fizinio aktyvumo intensyvumas darbe ir laisvalaikiu (proc.).

pasitenkinimo ir laimès jausmą, kurie yra subjektyvūs, tačiau vieni iš svarbiausių su sveikata susijusios gyvenimo kokybės dedamųjų. Nemaža dalis studentų mano, kad jų sveikata gera, tačiau dažnai mokymosi procesas yra sunkus fizinis ir psichinis krūvis, galintis daryti nepageidaujamą poveikị studentų sveikatai [11]. Pasak autoriaus, dažnai dèl didelio krūvio medicinos studentai kenčia miego trūkumą, prastai maitinasi, nepakankamai mankštinasi ir patiria nemažą stresą, todèl būsimų medikų fizinè ir psichinè sveikata yra prastesné, o nerimas, depresija ir neigiami gyvenimo būdo pokyčiai reiškiasi dažniau, negu kitų specialybių studentams. Studentų požiūrị ị sveikatą veikia ir studijų krypties pasirinkimas. Studentų pasitenkinimą savo sveikatos būkle gali lemti tai, kad kineziterapijos studijas renkasi jauni, fiziškai sveiki žmonès. Ugdymo institucijos uždavinys - sudaryti tokias sąlygas, kad studentai išlaikytų fizinị aktyvumą ir turètų galimybę ji gerinti, kad ateityje galètų tinkamai rūpintis savo pacientais.

Nagrinejant studentų fizinio aktyvumo rezultatus, nustatyta, kad studentai ir darbe, ir laisvalaikiu užsiima fizine veikla. Su fizine veikla susijusiu darbu užsiima 2,5 karto daugiau studentų, nei atvirkščiai $(\mathrm{p}<0,0001)$. Laisvalaikiu užsiimantys (52 proc.) ir neužsiimantys (48 proc.) fizine veikla pasiskirsto panašiai $(p>0,05)$. V. Dobrovolskij ir R. Stukas (2015) nustatè, kad daugiau nei trečdaliui visų mokslo sričių studentų laisvalaikiui būdingi lengvi fiziniai pratimai mažiausiai 4 val. per savaitę, tačiau tai nurodè daugiau biomedicinos (51,5 proc.), nei fiziniu ( 31,9 proc.) ir socialinių mokslų (43,1 proc.) studentų. JAV mokslininkai, lygindami medicinos studentų ir suaugusių gyventojų fizinio aktyvumo paplitimą laisvalaikiu, nustate, kad 78 proc. studentų fizinis aktyvumas atitinka rekomen- 
dacijas, laisvalaikiu fiziškai aktyvia veikla neužsiima tik 5,8 proc. studentų [13].

Nagrinètose srityse fizinès veiklos trukmė per parą skiriasi neženkliai ir trunka vidutiniškai 28,68 $\pm 7,04$ minutes, išskyrus labai intensyvų fizinį aktyvumą darbe, kuris trunka vidutiniškai 18 $\pm 13,04$ minučiu. Didžiosios dalies (67,9 proc.) Lietuvos aukštujų mokyklų studentų fizinio aktyvumo trukmé - daugiau nei 1 valanda per savaitę. Tai sudarytų apie 9 min. per parą. Biomedicinos srities studentu fizinio aktyvumo trukmè didesnè - 35,9 proc. respondentu fiziškai aktyvūs daugiau kaip 3 val. per savaitę $(9-26$ min. per parą), 38,1 proc. - 1-3 val. [12]. Panašūs rezultatai gauti ir kitose Europos šalyse. Nustatyta, kad 85,7 proc. studentu fizinio aktyvumo trukmè ilgesnè nei 3 val. per savaitę [14].

Fizinis aktyvumas mažina stresą ir su juo susijusius sveikatos sutrikimus [15-17]. Mažiau fiziškai aktyvūs studentai greičiau pavargsta, psichologinè būsena nestabili, dažniau patiria stresą, perdegimo ir depresijos bei nerimo simptomus [18]. Nepaisant to, trečdalis apklaustujų 5-6 valandas per parą dirba sẻdèdami. Panaši tendencija išlieka ir laisvalaikiu. Sèsliai praleidžiančių laisvalaikị iki 6 valandų per parą yra 25-27 proc. nuo visų apklaustų studentų. Panašūs rezultatai gauti ir kituose tyrimuose. Nustatyta, kad pasyvus poilsis (skaitymas, televizoriaus žiūrẻjimas ir kiti sèdimo poilsio būdai) laisvalaikiu būdingas 22,8 proc. studentų [19]. Menkas fizinis aktyvumas yra vienas būdingiausių modernios visuomenès gyvensenos bruožų, nes buities technika, automatizavimas, kompiuterizavimas, ryšių priemonių tobulèjimas sumažino poreikị judèti [4]. Autore nustatè, kad respondentai sėdèdami (darbe, prie televizoriaus, kompiuterio, skaitydami, megzdami ir pan.) kasdien praleidžia vidutiniškai apie 5 valandas (299 min.). Tyrimo rezultatai parode, kad ir darbe, ir laisvalaikiu studentams būdinga vidutinio intensyvumo fizinè veikla. Remiantis ankstesnių tyrimų rezultatais, Lietuvos aukštujų mokyklų studentų fizinis aktyvumas nepakankamas, fizinè saviugda menka, fiziniam aktyvumui trukdo negebèjimas sporto pratybų derinti su studijomis, dažnai studentai neturi noro, valios ir energijos dometis kitomis laisvalaikio praleidimo formomis [20-21]. Mokslininkai konstatuoja, kad pakankamai fiziškai aktyvus buvo tik kas penktas studentas. Tiriant studentų fizinį aktyvumą kitose Europos šalyse, nustatyta, kad tik 22,7 proc. studentų fizinis aktyvumas buvo pakankamas. Pakankamo fizinio aktyvumo paplitimui įtakos turejo lytis (tarp merginų paplitimas mažesnis) ir studento specialybė (fizinio aktyvumo paplitimas buvo didesnis tarp studentų, kurių specialybės susijusios su sportu) [22]. Tiriant Lenkijos medicinos universiteto studentų fizinį aktyvumą nustatyta, kad daugiausia fiziškai aktyvių buvo kineziterapijos studijų programos studentų (46 proc. respondentų buvo labai gero fizinio aktyvumo, 54 proc. - vidutinio fizinio aktyvumo), daugiausia nepakankamai fiziškai aktyviụ buvo medicinos studijų programos studentų (26 proc.) [23]. Puerto Rike atlikto tyrimo rezultatai parode, kad daugelio studentų fizinis aktyvumas buvo labai mažo (46,5 proc.) ar vidutinio intensyvumo (43,6 proc.) [13]. Mažo intensyvumo fizinis aktyvumas būdingesnis merginoms, nei vaikinams [19]. Šiame tyrime vidutini fizinio aktyvumo intensyvumą galëjo nulemti tai, kad tyrime dominavo merginos, sudariusios 86 proc. nuo visų respondentų.

\section{Išvados}

1. Kineziterapijos studijų programos studentai yra patenkinti savo gyvenimo kokybe ir sveikatos būkle, tačiau nustatytas jų fizinio aktyvumo intensyvumo lygis yra vidutinis.

2. Šio tyrimo rezultatai turi reikšmès kineziterapijos studijų programos pedagogams bei praktikams. Fizinio aktyvumo įtakos sveikatai žinių sklaida ugdymo procese turètų būti nuosekli, skatinanti asmeninę, grupinę ir bendruomeninę fizinę elgseną.

3. Gautieji rezultatai galètų suteikti pagrindą studentų sveikatingumo programoms ir veiklai kurti, kad būtų nuosekliai ugdomas sveikatos supratimas, formuojamas sveikos gyvensenos stilius, teikiamos sveikos gyvensenos rekomendacijos, sveikatos išsaugojimo programos.

4. Palaikant ir gerinant būsimų kineziterapeutų savijautą, tikimès, pagerès ir pacientų priežiūros kokybė, todèl kartotiniai ir tęstiniai tyrimai yra aktualūs studentų gyvenimo ir sveikatos kokybės pokyčiu stebėsenai laiko atžvilgiu.

\section{Literatūra}

1. Juozulynas A., Jurgelènas A., Prapiestis J., Butikis M. Gyvenimo kokybès ir socialinių veiksnių tarpusavio ryšys. Gerontologija, 2010;11(1):37-42.

2. Ghosh RK, et al. Health-related quality of life and its growing importance in clinical practise. N Z Med J 2010;123(1313): 99-101.

3. Staškute I. Su sveikata susijusios gyvenimo kokybės samprata, stebèsenos ir vertinimo metodai bei reikšmè sveikatos politikoje. Sveikatos politika ir valdymas, 2014;1(6):7-19. doi:10.13165/SPV-14-1-6-01

https://doi.org/10.13165/SPV-14-1-6-01

4. Valintèlienè R., Varvuolienė R., Kranauskas A. Lietuvos gyventojų fizinis aktyvumas, vertinant GPAQ metodu. Visuomenès sveikata, 2012;4(59):67-75.

5. Dore I, O'Loughlin JL, Beauchamp G, Martineau M, Fournier L. Volume and social context of physical activity in association with mental health, anxiety and depression among youth. Prev Med 2016;91:344-50.

https://doi.org/10.1016/j.ypmed.2016.09.006

6. Flueckiger L, Lieb R, Meyer AH, Witthauer C, Mata J. The importance of physical activity and sleep for affect on stressful days: two intensive longitudinal studies. Emotion. 2016;16(4):488-97.

https://doi.org/10.1037/emo0000143 
7. WHO global recommendations on physical activity for health. 2011;12:23.

8. Gužauskas D., Mikutavičienė I. Universiteto studentų fizinio aktyvumo motyvacijos veiksniai: teoriniai požiūriai. Visuomenès sveikata, 2018;28(6):56-63.

https://doi.org/10.5200/sm-hs.2018.072

9. Global physical activity questionnaire (GPAQ). http://www.who.int/chp/steps/GPAQ/en/index.html. 2019.

10. Grinienè E. Studentų savos sveikatos vertinimas ir požiūris ị sveiką gyvenseną. Ugdymas. Kūno kultūra. Sportas, 2006;1(60):10-17.

https://doi.org/10.33607/bjshs.v1i60.601

11. Domantay JAA. Health-related quality of life of future physicians at a medical school in the Philippines: a cross-sectional study. J Sagepub 2014;1-9.

https://doi.org/10.1177/2158244014545459

https://doi./org/ 10.1177/2158244014545459

12. Dobrovolskij V., Stukas R. Lietuvos aukštųų universitetinių mokyklų studentų fizinio aktyvumo ypatumai. Visuomenès sveikata, 2015;1:22-29.

13. Cruz S, Fabián C, Pagán I, Ríos J, González A, Palacios C et al. Physical activity and its associations with sociodemographic characteristics, dietary patterns, and perceived academic stress in students attending college in Puerto Rico. P R Health Sci J. 2013;32(1):44-50.

14. Moreno-Gómez C, Romaguera-Bosch D, Tauler-Riera P, BennasarVeny M, Pericas-Beltran J, Aguilo-Pons A et al. Clustering of lifestyle factors in Spanish university students: the relationship between smoking, alcohol consumption, physical activity and diet quality. Public Health Nutr 2012;15(11):2131-2139.

https://doi.org/10.1017/S1368980012000080

15. Chen JY, Xiang HJ, Jiang PP, Yu L, Jing Y, Li F, et al. The role of healthy lifestyle in the implementation of regressing suboptimal health status among college students in China: a nested casecontrol study. Int J Environ Res Public Health 2017;14(3):240. https://doi.org/10.3390/ijerph14030240

16. Leyfa AV, Zheleznyak YD. Influence of physical activity on students' life quality. J PES 2017;21(5):244-248.

https://doi.org/10.15561/20755279.2017.0507

https://doi.org/10.15561/20755279.2017.0507

17. Harris J. Physical education teacher education students' knowledge, perceptions and experiences of promoting healthy, active lifestyles in secondary schools. J PE SP 2014;19(5):466-480. http://dx. doi.org/10.1080/17408989.2013.769506 https://doi.org/10.1080/17408989.2013.769506

18. Jonsdottir IH, Rödjer L, Hadzibajramovic E, Börjesson M, Ahlborg G. A prospective study of leisure-time physical activity and mental health in Swedish health care workers and social insurance officers. Prev Med 2010;5(51):373-377.

https://doi.org/10.1016/j.ypmed.2010.07.019

19. Stanford FC, Durkin MW, Stallworth JR, Blair SN. Comparison of physical activity levels in physicians and medical students with the general adult population of the United States. J Phys Sports Med 2013;41:86-92. doi.org/10.3810/psm.2013.11.2039 https://doi.org/10.3810/psm.2013.11.2039

20. Tamošauskas, P. Studentų fizinio ugdymo atsinaujinimo gai- rès. Kultūra - ugdymas -visuomenè: mokslo darbai. Kaunas: Akademija, 2005;1:379-384.

21. Vaščila V., Gargasas S., Vyskupaitis E., Raupelis A. Kūno kultūros pratybų veiksmingumas pirmo kurso studentų požiūriui ị kūno kultūrą. Kultūra - ugdymas - visuomenè: mokslo darbai. Kaunas: Akademija, 2005;1:385-387.

22. Molina AJ, Varela V, Fernández T, Martín V, Ayán C, Cancela JM. Unhealthy habits and practice of physical activity in Spanish college students: the role of gender, academic profile and living situation. Adicciones 2012;24(4):319-327.

https://doi.org/10.20882/adicciones.82

23. Dąbrowska-Galas M, Plinta R, Dąbrowska J, Skrzypulec-Plinta V. Physical activity in students of the medical university of Silesia in Poland. Phys Ther 2013;93(3):384-392.

https://doi.org/10.2522/ptj.20120065

\section{STUDENT PHYSICAL ACTIVITY INTENSITY: IN THE CONTEXT OF HEALTH-RELATED QUALITY OF LIFE}

R.Jankauskienè, G.Šniepienè

Keywords: physical activity intensity, health-related quality of life, physiotherapy students.

Summary

Information on health-related quality of life is important for assessing health risk, health social factors, health system effectiveness, creating health promotion and prevention programs, and determining priority goals of health and public policy. The aim of the study was to evaluate the physical activity intensity of physiotherapy program students. The study was performed using Global physical activity questionnaire prepared by WHO. Questions was included about the physical activity at work, during recreation and while travelling to and from the places (walking or cycling) as well as sedentary behavior (sitting at work, at home etc.). Data analysis was performed using corresponding Analysis guide. Respondents was classified into low, moderate and high groups of physical activity intensity according to their total physical activity. The study included 127 students ( $86 \%$ female and 14\% male). The mean age was $24.67 \pm 3.76$ years. Student satisfaction for their quality of life was determine: there are five times more satisfied and very satisfied $(65 \%)$ than dissatisfied and very dissatisfied (13\%). A similar trend was observed for health satisfaction: four times more students are satisfied and very satisfied for their health compared to dissatisfied and very dissatisfied. Majority of respondents (74\%) don't work during studies. Working students have physical activity experience at work ( $71 \%$ of working students). Meanwhile, in leisure time the distribution of physically active and inactive respondents is quite similar $-52 \%$ and $48 \%$, respectively. In general, physical activity takes about $30 \mathrm{~min}$. per day. Students in average spent about 6 hours per day while sitting. Sedentary behavior is more prevalent in leisure time. Moderate physical intensity of students was determined, both at work and in leisure time. In conclusions, the results will provide the basis for creating wellness programs and activities of students, educating health awareness and health perception, modeling a healthy lifestyle and providing healthy lifestyle recommendations.

Correspondence to: r.jankauskiene@kvk.lt

Gauta 2019-10-17 